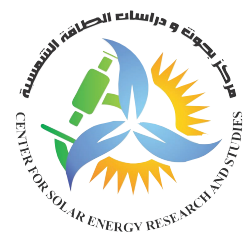

\title{
Wind Resource Assessment for southern part of Libya: Case Study of Hun
}

\author{
Hiba Shreif ${ }^{1}$, W. El-Osta ${ }^{2 \star}$, A. Yagub ${ }^{3}$ \\ ${ }^{1}$ Energy Management Dept., University of Tripoli, Tripoli, Libya, \\ ${ }^{2}$ Center for Solar Energy Research and Studies, Tajoura, Tripoli-Libya, \\ ${ }^{3}$ University of Michigan, Michigan USA \\ e-mail: ${ }^{2}{ }^{*} \_w e d a d @ h o t m a i l . c o m$
}

\begin{abstract}
The purpose of this study is to analyze the wind energy resource potential at Hun. Wind data was analyzed using different statistical models and calculations were performed to forecast wind energy \& power density at the site. Energy production was estimated using different wind turbines which were selected according IEC standards criteria and performance of these wind turbines. Detailed wind resource data analysis was performed for the proposed site using Excel spreadsheet for one-year period from (April 2011 to March 2012). The wind data are measured at four heights of $(20 \mathrm{~m}, 40 \mathrm{~m}, 60 \mathrm{~m}$ and $61 \mathrm{~m})$ above ground level (a.g.l). The analysis showed that the annual average wind speed is $5.69 \mathrm{~m} / \mathrm{s}$ and the power density is about $190 \mathrm{~W} / \mathrm{m} 2$ at $61 \mathrm{~m}$ height. It could be noticed that at $61 \mathrm{~m}$ height, the highest scale parameter is $7.25 \mathrm{~m} / \mathrm{s}$ in April while the lowest scale parameter is $5.71 \mathrm{~m} / \mathrm{s}$ in October. The annual shape and scale parameters range from 2.27 at $61 \mathrm{~m}$ to 2 at $20 \mathrm{~m}$, and from $6.42 \mathrm{~m} / \mathrm{s}$ at $61 \mathrm{~m}$ to $5 \mathrm{~m} / \mathrm{s}$ at $20 \mathrm{~m}$, respectively. $90 \%$ of the speeds are below $11 \mathrm{~m} / \mathrm{s}, 84 \%$ are below $10 \mathrm{~m} / \mathrm{s}$ and $50 \%$ are above $6 \mathrm{~m} / \mathrm{s}$. The maximum speed is $21 \mathrm{~m} / \mathrm{s}$ with $0.14 \%$ occurrence. The wind shear exponent was evaluated as 0.18 and the roughness length for the site as $0.17 \mathrm{~m}$, which indicates that the roughness class for the location is 2.5 . According to the performed analysis, the wind turbines suitable for this site should be of class III/B. Comparison of three wind turbines indicated that Vestas V112-3000 gave the highest capacity factor of $42 \%$ in April and an availability of $83 \%$ while Nordex N1002500 gave capacity factor of $41 \%$ for the same month and availability of $83.7 \%$.
\end{abstract}

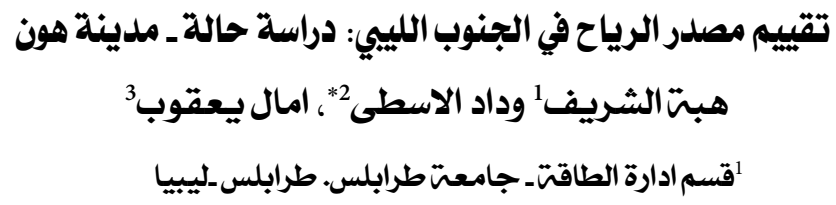

* Corresponding author 


\title{
2مركز بحوث ودراسات الطاقت الشمسيتة. طرابلس-ليبيا \\ جامعتميتشيجان، ميتشيجان. الولايات المتحدة الامريكيكتر
}

\begin{abstract}
ملحخص: تستهدف هذه الورقت تقييهم مصدر الرياح قِّ مدينت هون. فقد تم تحليل معلومات الرياح باستخدام نماذج إحصائيت، حيث

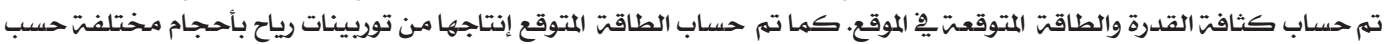

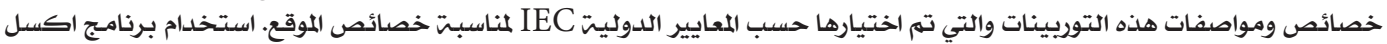

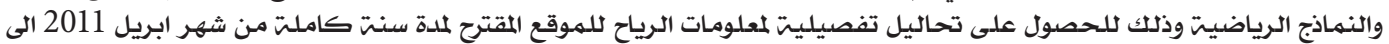

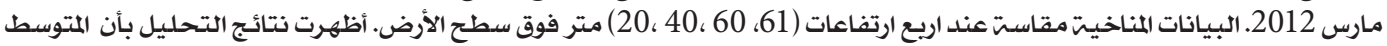

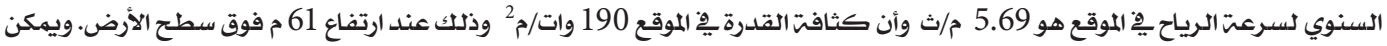

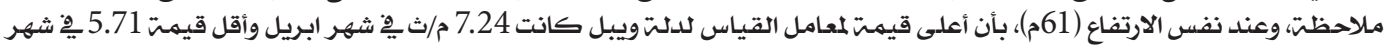

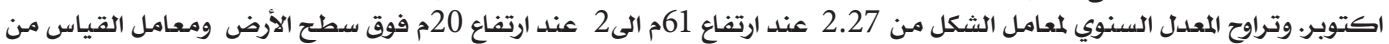

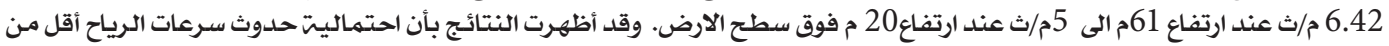

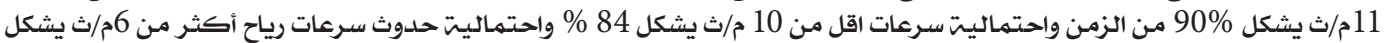

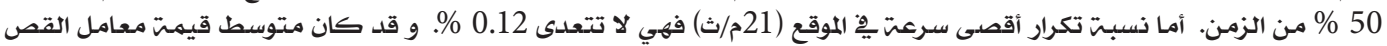
للمنحنى الرأسي لسرعت الرياح 0.18 و طول خشونت السطح

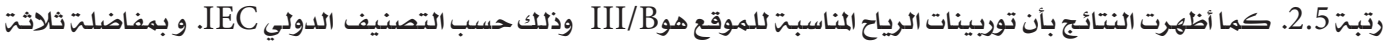

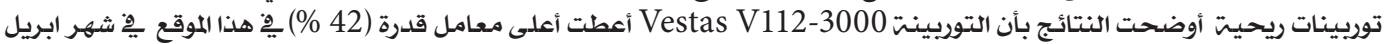

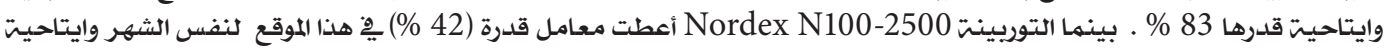
قدرها 83.7 ق 83.
\end{abstract}

Keywords: wind potential; wind energy; capacity factor; wind turbine classes; availability;

\section{INTRODUCTION}

Energy is a basic element of any economic development and electric energy is an important index of a country's economical and technological progress. Libya currently relies entirely on the oil and natural gas for electricity production. In the wake of the dwindling of fossil fuel reserves, rising costs of this type of fuel and the negative environmental impacts such as air pollution, acid rain and greenhouse effects associated with it, renewable energy have gained great interest or attention.

World dependence on fossil fuel and its impact on the international economy and environment has created several global issues. The world challenges for sustainable development are climate change or impacts, energy security and energy access. According to the International Renewable Energy (IRENA), the total global installed renewable energy capacity by end of 2018 is $2351 \mathrm{GW}$, while in Africa is about $46.27 \mathrm{GW}$ and in Libya only 5 MW[1]. IRENA - Renewable energy highlights of March 2019, showed that the highest share comes from hydropower $50 \%$ of total installed renewable capacity while wind energy constitutes $24 \%$ with installed capacity of $564 \mathrm{GW}$ by end of 2018[2]. Africa share is $5.464 \mathrm{GW}$ and Libya none, which shows that plans and programs should be devised to catch-up the world progress in harnessing this clean energy free resource. Latest statistics of World Wind Energy Association (WWEA) showed that the world total installed wind energy capacity had reached 600 GW by Feb- 2019 and the added capacity in 2018 is 53.9 GW [3].

Assessment of wind energy potential or any other energy resource potential is an important issue since any national strategy depends on the resources available for the country to be harnessed and extracted. Wind resource assessment (WRA) is important for investors and decision makers. The total world energy inland potential is estimated by the WWEA at about 95 TW[4], which is more than enough to meet the world energy demand.

Wind energy was assessed in Libya at several previous works [5-7] and the potential was estimated by 
several international studies in as part of African countries [8,9] or as a part of the world [10]. All these studies indicated that the potential is high [11]. It can supply the national electric energy demand and would reduce dependence on oil and natural gas power plants as well as it will mitigate the problems of the electric network blackout and provide a solution to all electric problems. Potential for establishing wind power plants in Libya and the wind energy potential in the Northern region was investigated $[12,13]$. In present work the wind potential of a site in the Southern part of Libya (Hun) was investigated in order to assess the potential of this region. Weibull distribution model was used and compared with real wind speed distribution at this site. Weibull parameters were determined at four heights for each month. Wind speed variation (seasonal and diurnal) was estimated at 4 - heights above ground level (a.g.l.). Energy output of different sizes of WECS's was determined and the capacity factor was evaluated for each WECS at the site. The most probable wind speed and the maximum energy carrier wind speed or wind speed that will contribute to maximum energy at the site were investigated for each month. Wind shear coefficient and the turbulence intensity were evaluated.

\section{CASE STUDY OF HUN CITY:}

\subsection{Site Description}

The city of Hun is within a semi-arid environment, in the north central part of Libya. The geographic coordinates for Hun: $29^{\circ} 07^{\prime} 48^{\prime \prime} \mathrm{N}$ Latitude, $1^{\circ} 57^{\prime} 00^{\prime \prime}$ E Longitude. Figure (1) shows the map of the area around Hun. It lies at the center of the map.

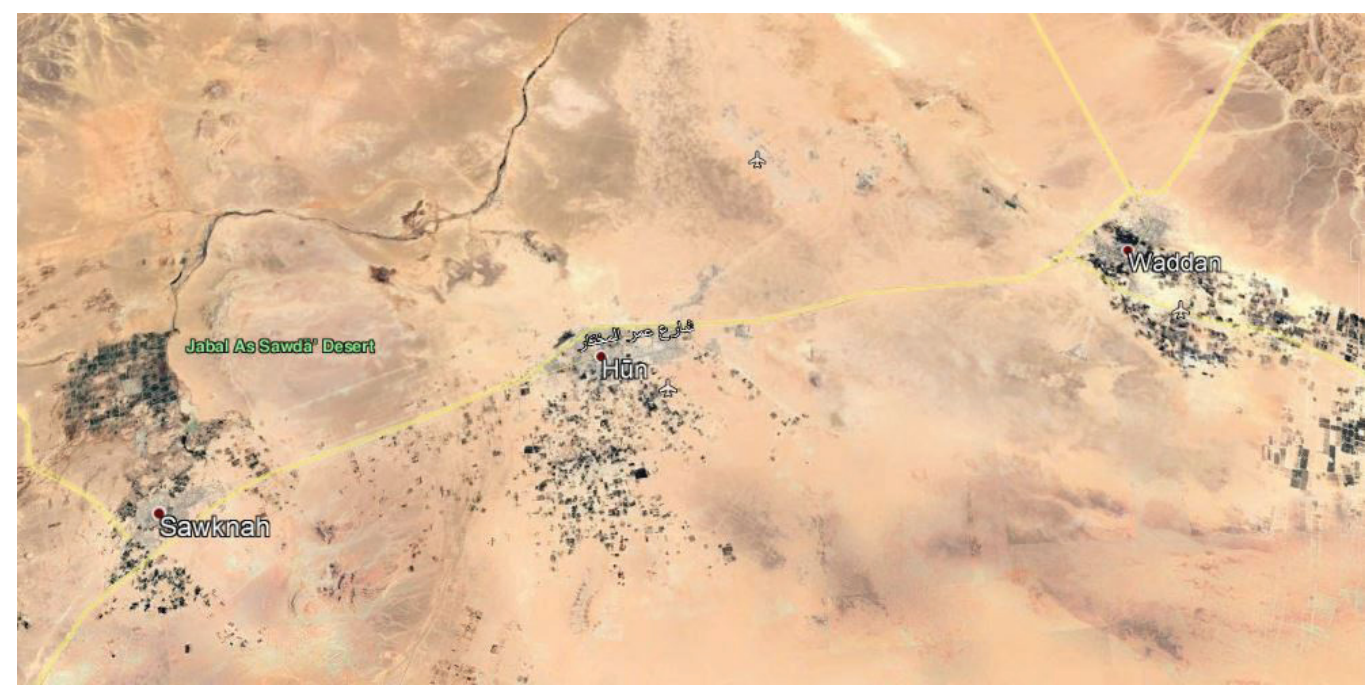

Figure (1). A map for the area around the site of Hun.

Hun is located at the center of the above map within a plane area bounded by two mountains to the east and west.

Hun is linked to northwards and southwards by a highway, thus connecting it with the coastal highway and the southwest and southeast of Libya. Along this highway, Hun is also connected with the towns of Suknah to the west and Waddan to the east. The dot-dashed line (shown in the map) is the main power line going through Hun. 


\subsection{Data screening and validation}

Wind data of Hun was provided by REAoL. It included wind speed records of 10 minutes average for four heights $(20 \mathrm{~m}, 40 \mathrm{~m}, 60 \mathrm{~m}$ and $61 \mathrm{~m}$ a.g.1.), wind direction at two levels, pressure, temperature and solar radiation at $4 \mathrm{~m}$ a.g.l. as shown in Figure 2.

Data screening was performed for all raw data to determine missing or inaccurate readings for the anemometers. The readings of the spreadsheet began at (3/4/2011 9:20) and ended at (4/19/2012 9:40). The data used in this case study was chosen as one-year period starting (1/4/2011 0:00) to (31/3/2012 0:00).

\section{Meteorological Tower}

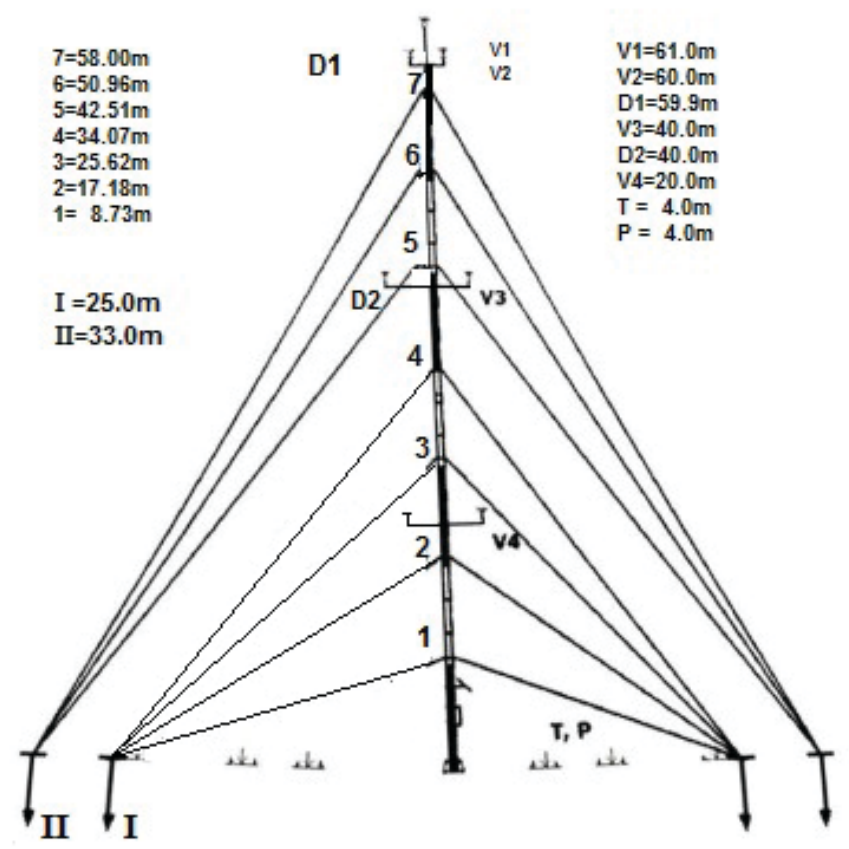

Figure (2) Schematic Diagram of a Meteorological Tower

All raw wind data was screened for missing or inaccurate data. Only three (3) missing data was observed, as shown in Table 1.

Table (1). Missing data values date and time

\begin{tabular}{|c|c|c|}
\hline No. & Date & Time \\
\hline 1 & $13-12-2011$ & $11: 30$ \\
\hline 2 & $27-1-2012$ & $9: 00$ \\
\hline 3 & $27-1-2012$ & $9: 30$ \\
\hline
\end{tabular}

The errors expected from such missing data could be neglected. It can be seen from the above table that this missing data could be due to data downloading when removing memory card from the data logger. Since they are small in number and happened for shorter time periods, it was filled by averaging of the previous and their next reading data sets. 


\section{THEORETICAL BACKGROUND}

Wind speed varies with time and space. To estimate wind energy potential of any proposed site, the wind data collected from the location should be properly analyzed, correlated and predicted. Literatures recommend using available long-term wind data from meteorological stations near the candidate site to be used for making preliminary estimates of wind resource potential for a proposed site.

In this project, wind measurement system was installed at the site (Hun). It provided the average wind speed, standard deviation, wind direction, air pressure, air temperature and site solar radiation for ten minutes time average intervals. This short-term wind data is further grouped over time and analyzed with the help of statistical models to make precise estimates of the energy available in the wind.

\subsection{Wind speed frequency distribution}

Wind speed frequency distribution at a site play an important role in evaluating wind potential at that site. There are several probability functions that could be used to describe wind characteristics at the site but Weibull distribution is the most used in wind energy field since it fit most sites in the world. Weibull distribution function of wind speed $\mathrm{fw}(\mathrm{v})$ is a two parameters function; scale parameter (C) and shape parameter $(\mathrm{k})$. It provides important information on wind regime. Knowing the distribution helps estimation of wind power density and expected energy production from WECS's at the site. It is an important tool to determine the probability density function and cumulative frequency function. The probability density function $(f(V))$ indicates the fraction of time (or probability) for which the wind is at a given velocity V. The probability density function can be modeled for a desired site as [14]:

$$
\begin{aligned}
& f_{\mathrm{W}}(v)=\frac{\mathrm{k}}{\mathrm{c}}\left(\frac{\mathrm{v}}{\mathrm{c}}\right)^{\mathrm{k}-1} \exp ^{-\left(\frac{v}{\mathrm{c}}\right)} \\
& \text { for }(\mathrm{v}>0, \mathrm{k}>0 \text { and } \mathrm{C}>0) \\
& \text { where: } \mathrm{C} \text { represents the Weibull scale parameter }(\mathrm{m} / \mathrm{s}) \text { and } \mathrm{k} \text { denotes the dimensionless Weibull shape }
\end{aligned}
$$
parameter.

\subsection{The cumulative distribution function:}

The cumulative distribution function, $\mathrm{F}(\mathrm{V})$, of the velocity $\mathrm{V}$ gives the fraction of time (or probability) that the wind velocity is equal or lower than V. Thus, the cumulative distribution $F(V)$ is the integral of the probability density function. It is given by [14]:

$$
F(v)=\int_{0}^{\alpha} f(v) d v=1-\exp ^{\left[\frac{v}{c}\right]^{k}}
$$

\subsection{Estimating $\mathrm{c}$ and $\mathrm{k}$ by standard deviation method}

There are several methods to estimate the values of the $\boldsymbol{k}$ and $\boldsymbol{C}$ parameters such as:

1. Graphical method

2. Standard deviation method

3. Moment method

4. Maximum likelihood method and

5. Energy pattern factor method

In this paper, the standard deviation method (or Justus method) has been utilized and was adopted to estimate the shape parameter $(\boldsymbol{k})$ for its acceptable accuracy range and ease of utilization [8]. Weibull shape 
parameter $(\boldsymbol{k})$ can be determined by dividing standard deviation with average velocity from the relation [15- 21]:

$$
k=\left(\frac{\sigma}{\bar{v}}\right)^{-1.086}
$$

$\boldsymbol{k}$ can be easily determined from the values for $\boldsymbol{\sigma}_{\mathrm{v}}$ and $\mathbf{V}_{\mathrm{m}}$ which are calculated from the given wind speed data set. Once $\mathrm{k}$ is determined, the scale factor $(\boldsymbol{C})$, can be computed as:

$$
c=\frac{\bar{v}}{\Gamma(1+1 / k)}
$$

The average wind speed $\mathrm{Vm}$ and the standard deviation can be obtained as:

$$
\begin{aligned}
& \bar{v}=\frac{1}{\mathrm{n}} \sum_{i=1}^{n} v_{i} \\
& \sigma^{2}=\frac{1}{\mathrm{n}-1} \sum_{\mathrm{i}=1}^{\mathrm{n}}\left(v_{\mathrm{i}}-\bar{v}\right)^{2}
\end{aligned}
$$

The average wind speed $\mathrm{v}_{\mathrm{m}}$ and the standard deviation can be calculated by using the estimated Weibull parameters as follow:

$$
\begin{aligned}
& \bar{v}=\int_{0}^{\infty} v f_{w}(v) d v \\
& v_{m}=\mathrm{C} \Gamma\left(1+\frac{1}{k}\right) .
\end{aligned}
$$

where $\mathrm{G}(\mathrm{x})$ is the Gamma function. The gamma function is given as [14]:

$$
\Gamma(x)=\int_{0}^{\infty} \exp (-u) u^{x-1} d x
$$

The standard deviation of wind speed can also be calculated in terms of Weibull parameters as:

$$
\sigma=c\left[\Gamma\left(1+\frac{2}{k}\right)-\Gamma^{2}\left(1+\frac{1}{k}\right)\right]^{1 / 2}
$$

\subsection{Most probable wind speed and maximum energy carrier:}

The most probable wind speed $v_{m p}$ of a region, and maximum energy carrier $v_{\max }$ of wind speed for wind energy converters are determined as [14, 16-22]:

$$
\begin{aligned}
& v_{m p}=c \cdot\left(1-\frac{1}{k}\right)^{1 / k} \ldots \\
& v_{\max E}=c \cdot\left(1-\frac{2}{k}\right)^{1 / k}
\end{aligned}
$$

The two wind speeds are very useful to the wind energy investors. Essentially, the $v_{\mathrm{mp}}$ simply tells the most frequently wind speed for a given wind probability distribution. The $v_{\max }$ is utilized to estimate the rated wind speed because the speed carrying the maximum amount of energy and the design wind speed of the turbine should be as close as possible.

\subsection{The wind power density}

The wind power density PD using the Weibull model is expressed as [14]:

$$
P_{D}=\frac{1}{2} \rho c^{3} \Gamma\left(1+\frac{3}{k}\right)
$$

Where $\rho$ is the air density. 


\subsection{Turbulence intensity (T.I)}

In addition to the average wind speed which characterizes the property of the site, the standard variation should be evaluated; since it indicates the rate of variation of wind speed over a time period. Standard deviation indicates the deviation of each wind speed from the mean value. It is also important to evaluate the turbulence intensity at a site for many reasons. It changes with the mean wind speed, surface roughness, atmospheric stability and topographic features. When selecting the sites for wind energy project, it is essential to determine the turbulence intensity of the location for purpose of power production stability as well as the life time of system accessories.

Basically, the turbulence intensity $(I T)$ is defined as the ratio between the standard deviation $\left(\boldsymbol{\sigma}_{\mathrm{u}}\right)$ of the wind speed, and the 10-minute mean wind speed $\left(\mathrm{V}_{10 \mathrm{~m}}\right)$. It is given by:

$$
I T=\frac{\sigma_{u}}{v_{10 m}}
$$

Lower values of $\sigma_{u}$ indicate the uniformity of the site wind speed data.

\subsection{Extrapolation of wind speed with height}

Due to the effect of the terrain properties different structures exist at the site on the air flow over the ground the velocity of wind at the ground surface, theoretically, is assumed to be zero. The wind speed is then increased with height up to a certain height. The rate of wind shear depends on the type of terrain at the site. The velocity profile commonly can be represented by logarithmic law which is function of the roughness length or power law, which depends on power exponent.

\subsection{1. $\log \operatorname{law}$}

The calculation can be performed by the following relation:

$$
v\left(Z_{R}\right)=\frac{v(Z) \ln \left(\frac{Z_{R}}{z_{0}}\right)}{\ln \left(\frac{Z}{z_{0}}\right)}
$$

where:

$v\left(\mathbf{Z}_{\mathrm{R}}\right)$ : velocity at heights $Z_{\mathrm{R}}$

$v(Z)$ : velocity at heights $Z$

$\mathbf{z}_{\mathbf{0}}$ : surface roughness length $(\mathrm{m})$.

The surface roughness length can be determined if the wind speed is known at two different heights at the site.

\subsection{2. power law}

The basic formula is given as:

$$
\frac{v(Z)}{v\left(Z_{R}\right)}=\left[\frac{Z}{Z_{R}}\right]^{\alpha}
$$

\section{where:}

$\mathrm{v}(\mathrm{Z})$ : wind speed at height $\mathrm{Z}$,

$v(Z r)$ : reference wind speed at height $\mathrm{Zr}$ and 
$\boldsymbol{\alpha}$ : power law exponent

The value of the power exponent can be evaluated from above relation when two measurements of wind speed are known at the two heights. Several empirical formulas exist at the literature.

\subsection{Energy estimation of wind regimes}

In evaluating wind resource potential of a prospective site, it is important to determine the power density or available power of the wind per unit area of a wind rotor as well energy density. The wind energy density $\left(\mathbf{E}_{\mathbf{D}}\right)$ is the energy available in the regime for a unit rotor area and time.

Selecting wind turbines for a proposed wind farm and estimating its energy production needs to evaluate the most frequent wind velocity (VF-max), and the velocity that contributing the maximum energy (VE-max) at the site. The peak of the wind speed probability density curve represents VFmax where VE-max can be read from the peak of energy probability density curve.

Due to the cubic relationship of velocity and power, the contribution of $\mathbf{V}_{\mathbf{E} \text {-max }}$ for power generation is usually higher than $\mathbf{V}_{\mathrm{F} \text {-max }}$. Therefore, for selection of turbines in according to IEC classification, it was tried to found the turbine which has rated wind speed $\left(\mathbf{V}_{\mathbf{r}}\right)$ as close as possible for the site $\mathbf{V}_{\mathbf{E} \text {-max }}$ value. Selection of this kind of turbines will be advantageous to maximize the power production at such site. The energy production could be estimated in terms of frequency distribution $\mathrm{f}(\mathrm{u})$ at the site and power curve of the proposed wind turbine $\boldsymbol{P}(\boldsymbol{u})$ from its $\mathbf{V}_{\mathrm{ci}}$ to $\mathbf{V}_{\mathrm{c} \boldsymbol{}}$ as:

$$
P=\int_{0}^{\infty} f(u) P(u) d u=\int_{0}^{\infty} \frac{k}{A}\left(\frac{u}{A}\right)^{k-1} \exp \left(-\left(\frac{u}{A}\right)^{k}\right) P(u) d u
$$

\subsection{Capacity factor}

Capacity factor is an important factor for evaluating the performance of any prospective wind power farm or wind energy project. It is defined as the ratio of the actual energy produced by wind turbines at a site to that of the energy that could have been produced by these wind turbines if they had worked at their rated power. Mathematically, it is given as:

$$
C_{F}=\frac{E_{T}}{P_{R} \times T}
$$

where:

T: Time duration

$\mathbf{E}_{\mathrm{T}}$ : Energy actually produced by wind turbines

$\mathbf{P}_{\mathbf{R}}$ : Rated power of wind turbines

\section{10. Wind direction}

The wind direction is affected by site geography, global and local climatic conditions as well as by earth rotation. It varies with the lateral turbulence intensity and in coastal sites it can vary during the day and night. The distribution of the wind direction is represented by a Wind rose.

\subsection{Extreme value analysis}

Extreme winds are usually given in terms of 10 -minute mean wind speeds, with recurrence period of 1- year or 50-year. The 50-year wind speed is the 10-minute mean wind speed, which, on average, is exceeded 
once every fifty years. Determination of the 50 -year wind speed requires an extreme value of wind speed. According to the International Electrotechnical Commission standards, IEC 61400-1 (3rd. ed. 2005) [23], wind turbines are classified according to their ability to withstand extreme wind speeds at $50 \mathrm{~m}$ hub height, mean wind speed and turbulence intensity, such classification is presented in table (2). The following relations could be used:

For estimating the wind gust of 50-year period:

$$
V_{\text {eG50 }}(h)=1.4 V_{\text {eref }}\left[\frac{h}{h_{h u b}}\right]^{0.11}
$$

To estimate the annual gust the following relation could be used:

$$
V_{e G 1}(h)=0.75 V_{e G 50}(h)
$$

where:

$\mathrm{V}_{\mathrm{e} \text { ref }}$ : maximum wind speed or (extreme reference wind speed) expected to be as a mean value over 10 min period.

$\mathrm{V}_{\mathrm{G} 50}$ : maximum or extreme wind speed expected within 50 - years

$\mathrm{V}_{\mathrm{G} 1}$ : maximum or extreme wind speed expected within 1- year

TI15: characteristic turbulence intensity at a wind speed of $15 \mathrm{~m} / \mathrm{s}$

\begin{tabular}{|c|c|c|c|c|c|}
\hline \multicolumn{2}{|c|}{ Wind Turbine Class } & I & II & III & S \\
\hline Vref & $(\mathrm{m} / \mathrm{s})$ & 50 & 42.5 & 37.5 & Values \\
\hline $\mathrm{A}$ & $\operatorname{Iref}(-)$ & & 0.16 & & Specified \\
\hline B & $\operatorname{Iref}(-)$ & & 0.14 & & by the \\
\hline C & Iref (-) & & 0.12 & & Designer \\
\hline
\end{tabular}

Table (2). The IEC 61400-(3rd. ed.-2005) Wind turbine Classes [ 23]

where:

Vref: is the extreme reference wind speed averaged over 10-minutes.
A: designated category for higher turbulence characteristics
B: designated category for medium turbulence characteristics
C: designated category for lower turbulence characteristics
Iref: the expected turbulence intensity at $15 \mathrm{~m} / \mathrm{s}$

\subsection{Availability of wind turbine:}

The availability of a wind turbine at a site is an important factor for investors. It describes the operating probability of a wind turbine at a site. It could be estimated if the cut-in and cut-out wind speeds are known. Also, the percentage of time that a wind turbine is expected to work at its rated power could be estimated if the rated wind speed of the wind turbine is known. The availability factor $\left(\mathrm{A}_{\mathrm{F}}\right)$ of a given wind turbine with cut-in (Vci) and cut-out (Vco) wind speeds, can be calculated as [24,25]:

$$
\begin{aligned}
& A_{F}=P\left(v_{\text {in }} \leq v \leq v_{0}\right)=F\left(v_{0}\right)-F\left(v_{\text {in }}\right) \\
& =1-e^{-\left(\frac{2 v}{c}\right)^{k}}-\left[1-e^{-\left(\frac{\left.v_{i}\right)^{k}}{c}\right)^{k}}\right] \\
& =e^{-\left(\frac{v_{i n}}{c}\right)^{k}}-e^{-\left(\frac{2 v_{0}}{c}\right)^{k}}
\end{aligned}
$$




\section{RESULTS AND DISCUSSION}

Wind data of Hun was analyzed according to section (3). Microsoft excel spreadsheet was used for the analysis. The results are presented in the following sections.

\subsection{Seasonal and Diurnal pattern of Wind Speed at Hun}

The wind speed seasonal and diurnal variations at different heights are presented in Figures 3 to 5 . As it could be noticed that the highest wind speeds, for all months, are at $61 \mathrm{~m}$ height. April has the highest wind speed followed by February and January then May and June. The lowest value is in December. The calculation of the hourly average wind speeds was performed for wind records at the four heights. Figures 4 and 5 show the diurnal variation of wind speed at $61 \mathrm{~m}$. As it can be noticed in these figures that there is a variation in the diurnal pattern of wind speed. The site is exposed to low wind speed during the middle of the day, and high speeds during night time and early hours of the day.

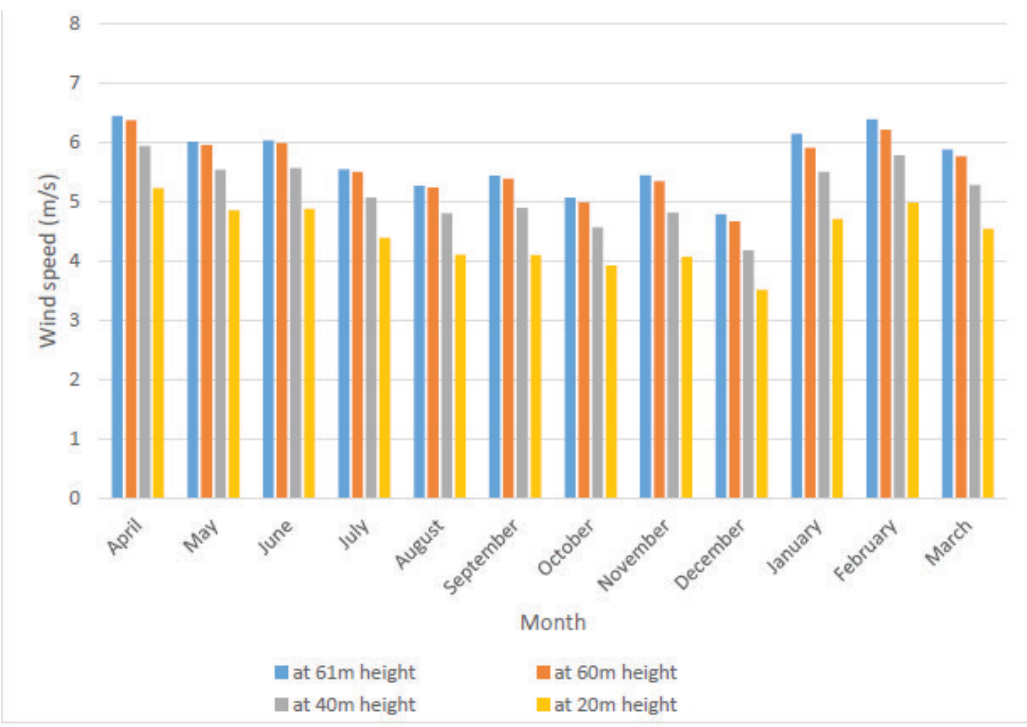

Figure (3) Annual average wind speed at different heights for Hun

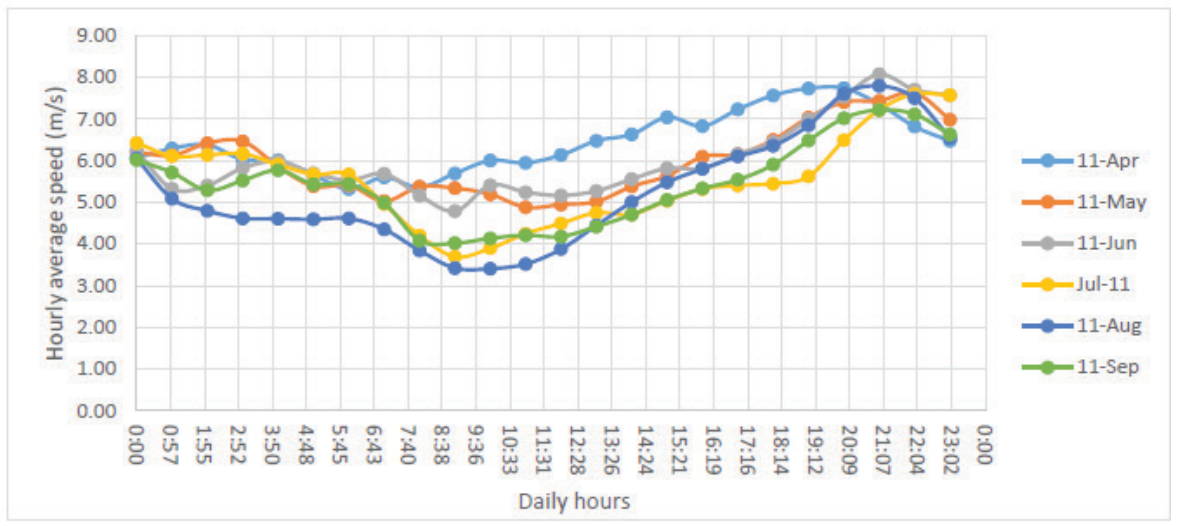

Figure (4) Wind speed diurnal pattern for Hun at $61 \mathrm{~m}$ a.g.l. (Apr-11 to Sep-11) 


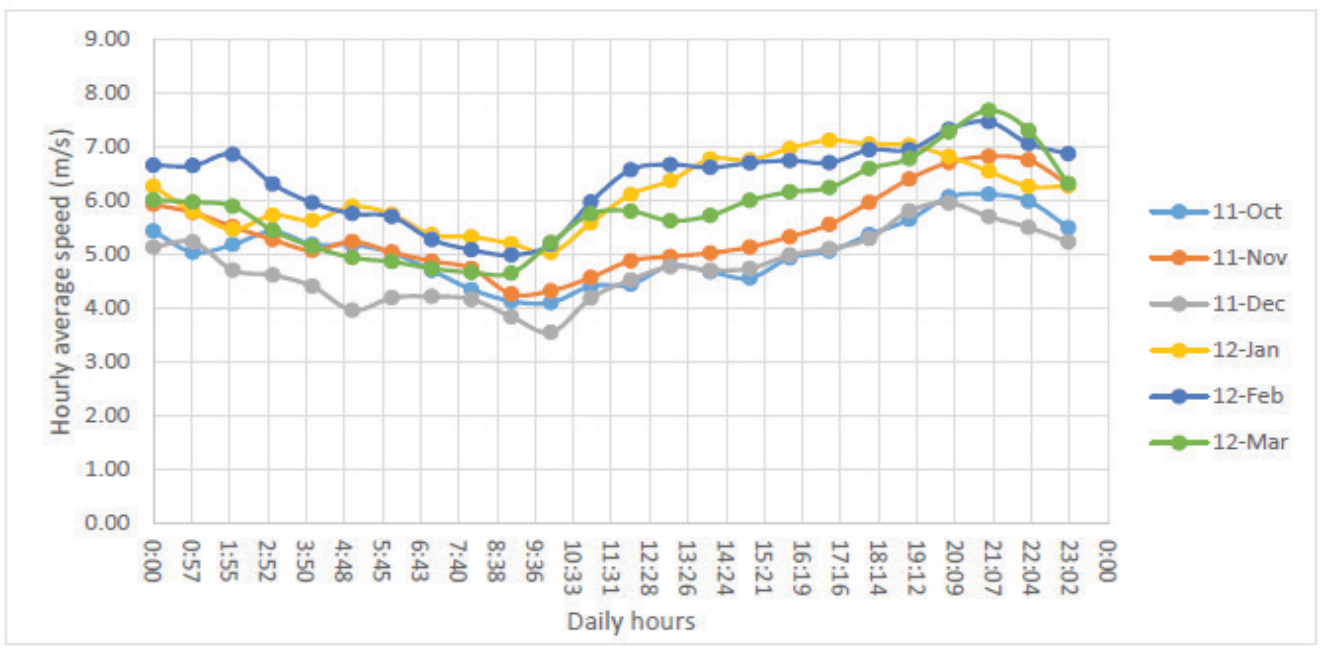

Figure (5) Wind speed diurnal pattern for Hun at $61 \mathrm{~m}$ a.g.l (Oct-11 to Mar-12)

\subsection{The wind speed probability distribution and calculation of Weibull parameters}

The monthly and annual Weibull shape and the scale parameters were calculated according to section (3.1) and (3.3). The results of Weibull parameters are presented in Table 3. At 61m height, the highest scale parameter (C) is $7.25 \mathrm{~m} / \mathrm{s}$ in April while the lowest scale parameter is $5.71 \mathrm{~m} / \mathrm{s}$ in October. The annual shape $(\mathrm{k})$ and scale parameters $(\mathrm{C})$ range from 2.27 at $61 \mathrm{~m}$ a.g.l. to 2 at $20 \mathrm{~m}$ a.g.l., and from $6.42 \mathrm{~m} / \mathrm{s}$ at $61 \mathrm{~m}$ to $5 \mathrm{~m} / \mathrm{s}$ at $20 \mathrm{~m}$.

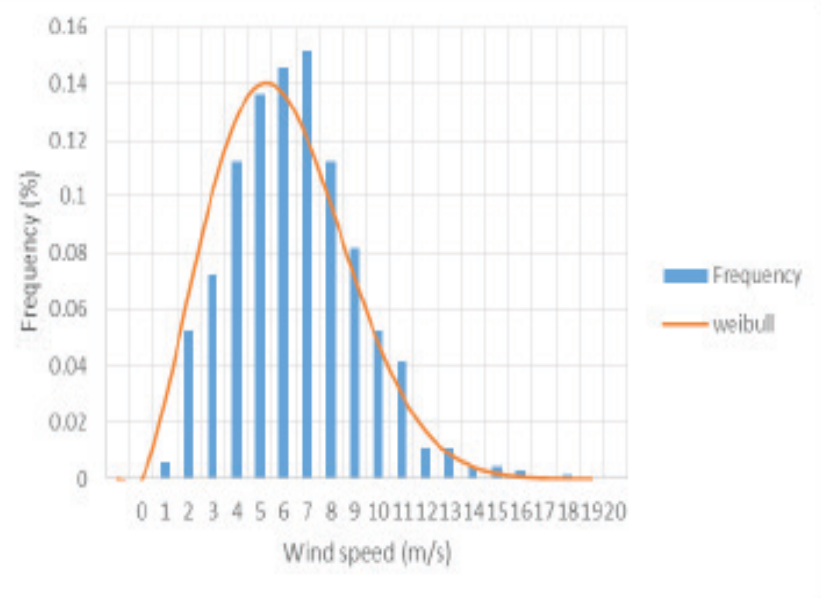

Figure 6. Comparison of observed wind speed and wind frequency simulated by the Weibull function (June-2011).

Wind speed frequency distribution was estimated by Weibull probability density function according to section (3.1) and compared to natural frequency or histogram obtained from wind speed observation at the site. An example of the comparison of the monthly observed wind speed frequency and wind frequency simulated by the Weibull function for (June-11 at $60 \mathrm{~m}$ ) is depicted in Figure (6). The similarity of both trends illustrates the good representation offered by such a model when compared to the actual measured data. 
Estimation and evaluation of distribution parameters monthly and annual values of these parameters are summarized in Table 3. The monthly values of the scale parameter $\boldsymbol{C}$ vary between $5.64-13.17$, while the monthly values of the shape parameter $\boldsymbol{k}$ varied between $1.97-9.13$.

Table 3. Shape parameters $(\mathrm{k})$ and scale parameters, $\mathrm{c}(\mathrm{m} / \mathrm{s})$ for Hun at different heights.

\begin{tabular}{|c|c|c|c|c|c|c|c|c|}
\hline \multirow{2}{*}{ Month } & \multicolumn{2}{|c|}{$\mathrm{V} @ 61 \mathrm{~m}$} & \multicolumn{2}{c|}{$\mathrm{V} @ 60 \mathrm{~m}$} & \multicolumn{2}{c|}{$\mathrm{V} @ 40 \mathrm{~m}$} & \multicolumn{2}{c|}{$\mathrm{V} @ 20 \mathrm{~m}$} \\
\cline { 2 - 9 } & $\mathrm{k}$ & $\mathrm{C}$ & $\mathrm{k}$ & $\mathrm{C}$ & $\mathrm{k}$ & $\mathrm{C}$ & $\mathrm{k}$ & $\mathrm{C}$ \\
\hline Apr-11 & 2.64 & 7.25 & 1.93 & 7.18 & 1.87 & 6.68 & 1.73 & 5.86 \\
\hline May-11 & 2.28 & 6.77 & 2.27 & 6.71 & 2.24 & 6.24 & 2.14 & 5.48 \\
\hline Jun-11 & 2.30 & 6.79 & 2.30 & 6.75 & 2.30 & 6.28 & 2.25 & 5.50 \\
\hline Jul-11 & 2.36 & 6.25 & 2.35 & 6.20 & 2.33 & 5.71 & 2.26 & 4.95 \\
\hline Aug-11 & 2.35 & 5.94 & 2.33 & 5.90 & 1.91 & 5.40 & 2.12 & 4.63 \\
\hline Sep-11 & 2.72 & 6.11 & 2.70 & 6.05 & 2.62 & 5.50 & 2.37 & 4.63 \\
\hline Oct-11 & 2.23 & 5.71 & 2.21 & 5.63 & 2.14 & 5.15 & 1.98 & 4.42 \\
\hline Nov-11 & 2.43 & 6.14 & 2.42 & 6.03 & 2.31 & 5.43 & 2.08 & 4.59 \\
\hline Dec-11 & 2.02 & 5.39 & 2.04 & 5.26 & 1.89 & 4.71 & 1.75 & 3.94 \\
\hline Jan-12 & 2.38 & 6.92 & 2.40 & 6.66 & 2.23 & 6.20 & 1.98 & 5.31 \\
\hline Feb-12 & 1.95 & 7.20 & 2.00 & 7.00 & 1.88 & 6.50 & 1.75 & 5.58 \\
\hline Mar-12 & 1.87 & 6.61 & 1.87 & 6.49 & 1.73 & 5.92 & 1.57 & 5.06 \\
\hline All year & 2.27 & 6.42 & 2.23 & 6.32 & 2.12 & 5.81 & 2.00 & 5.00 \\
\hline
\end{tabular}

\subsection{Cumulative distribution of wind velocity}

Cumulative distribution curve is constructed by plotting the cumulative time for which the wind velocity is below the upper limit of a wind class interval. Figure 7 shows an example of the cumulative curve for month of April-2011 at $61 \mathrm{~m}$. The figure shows that $90 \%$ of the speeds are below $11 \mathrm{~m} / \mathrm{s}, 84 \%$ are below $10 \mathrm{~m} / \mathrm{s}$ and $50 \%$ are above $6 \mathrm{~m} / \mathrm{s}$. The maximum wind speed is $21 \mathrm{~m} / \mathrm{s}$ with only $0.14 \%$ occurrence.

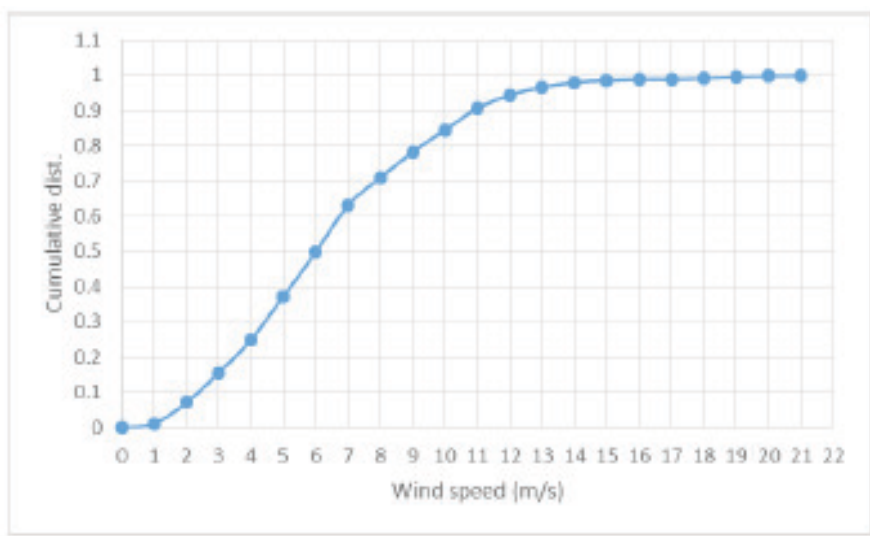

Figure (7) Cumulative distribution curve at $61 \mathrm{~m}($ Apr-11) 


\subsection{Wind Shear (velocity profiles)}

In this paper Eq. (15) was used to determine surface roughness length and Eq. (16) for power law exponent. These equations were presented in section (3). These values are then used to extrapolate wind speed to the turbine hub height by utilizing the power law approach.

As presented in table (4), the average value of the wind shear exponent is 0.18 , which can be classified as "Flat grass land or low shrubs". This description was taken from table (5) that illustrates the description for ranges of wind shear coefficient.
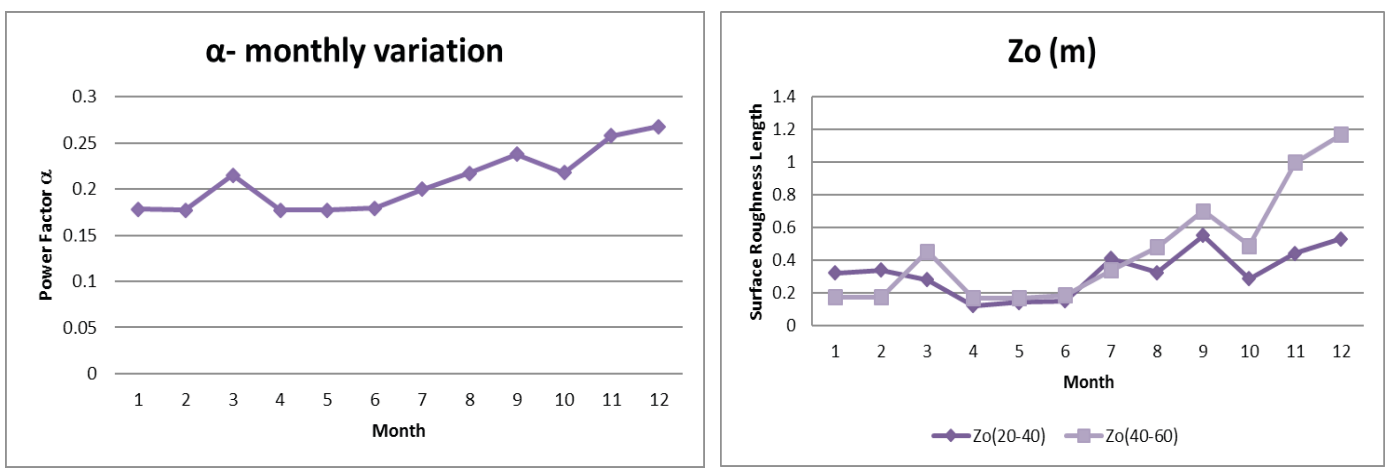

Figure (8) Monthly variation of power exponent. Figure (9) Monthly variation of surface roughness

The roughness length for the site has an average value of $0.17 \mathrm{~m}$. As it could be noticed in table 6, this value indicates that the roughness class for the location is 2.5 . The landscape types for this particular roughness class are shown in table (6). Figure (8) shows the monthly variation of power exponent with height at level 40-60 m a.g.l., while Figure (9) depicts the monthly variation of surface roughness length.

Table 4 - Wind shear exponent ( $\alpha$ ) and roughness length (Zo)

\begin{tabular}{|c|c|c|c|}
\hline & $\mathrm{V}(\mathrm{m} / \mathrm{s})$ & $\mathrm{Z}(\mathrm{m})$ & Wind Shera Exponent \\
\hline \multirow{3}{*}{ Power Law } & 6.37 & 60 & 0.18 \\
\cline { 2 - 3 } & 5.93 & 40 & Roughness Length $(\mathrm{m})$ \\
\hline \multicolumn{2}{|c|}{} & 0.17 \\
\hline \multirow{3}{*}{ Log Law } & 6.37 & 60 & 0.10 \\
\cline { 2 - 3 }
\end{tabular}

Table 5. Wind shear coefficient [ 26]

\begin{tabular}{|l|l|}
\hline Landscape Type & Friction Coefficient (a) \\
\hline Lakes, ocean and smooth hard ground & 0.10 \\
\hline Grasslands (ground level) & 0.15 \\
\hline Tall crops, hedges and shrubs & 0.20 \\
\hline Heavily forested land & .025 \\
\hline Small town with some trees and shrubs & 0.30 \\
\hline City areas with high rise buildings & 0.40 \\
\hline
\end{tabular}


Table 6 - Roughness class and landscape type for roughness length values [26-28]

\begin{tabular}{|l|l|l|}
\hline $\begin{array}{l}\text { Roughness } \\
\text { Class }\end{array}$ & $\begin{array}{l}\text { Roughness } \\
\text { Length }(\mathrm{m})\end{array}$ & Landscape Type \\
\hline 0.0 & 0.0002 & Water Surface. \\
\hline 0.5 & 0.0024 & $\begin{array}{l}\text { Completely open ground with a smooth surface, e.g. concrete runways at the } \\
\text { airports, mowed grassland, etc. }\end{array}$ \\
\hline 1.0 & 0.0300 & $\begin{array}{l}\text { Open farming areas fitted with no fences and hedgerows and very scattered } \\
\text { buildings. Only softly rounded hills. }\end{array}$ \\
\hline 1.5 & 0.0550 & $\begin{array}{l}\text { Farming land dotted with some houses and 8m tall sheltering hedgerows } \\
\text { within a distance of some } 1250 \text { m. }\end{array}$ \\
\hline 2.0 & 0.1000 & $\begin{array}{l}\text { Farming land dotted with some houses and 8m tall sheltering hedgerows } \\
\text { within a distance of some 500 m. }\end{array}$ \\
\hline 2.5 & 0.2000 & $\begin{array}{l}\text { Farming land dotted with many houses, shrubs and plants, or with 8m tall } \\
\text { sheltering hedgerows within a distance of some 250 m. }\end{array}$ \\
\hline 3.0 & 0.4000 & $\begin{array}{l}\text { Villages, hamlets and small towns, farming land with many or tall sheltering } \\
\text { hedgerows, forest areas and very rough and uneven terrain. }\end{array}$ \\
\hline 3.5 & 0.8000 & Large cities dotted with high rise buildings. \\
\hline 4.0 & 1.6000 & Very large cities dotted with high rise buildings and skyscrapers. \\
\hline
\end{tabular}

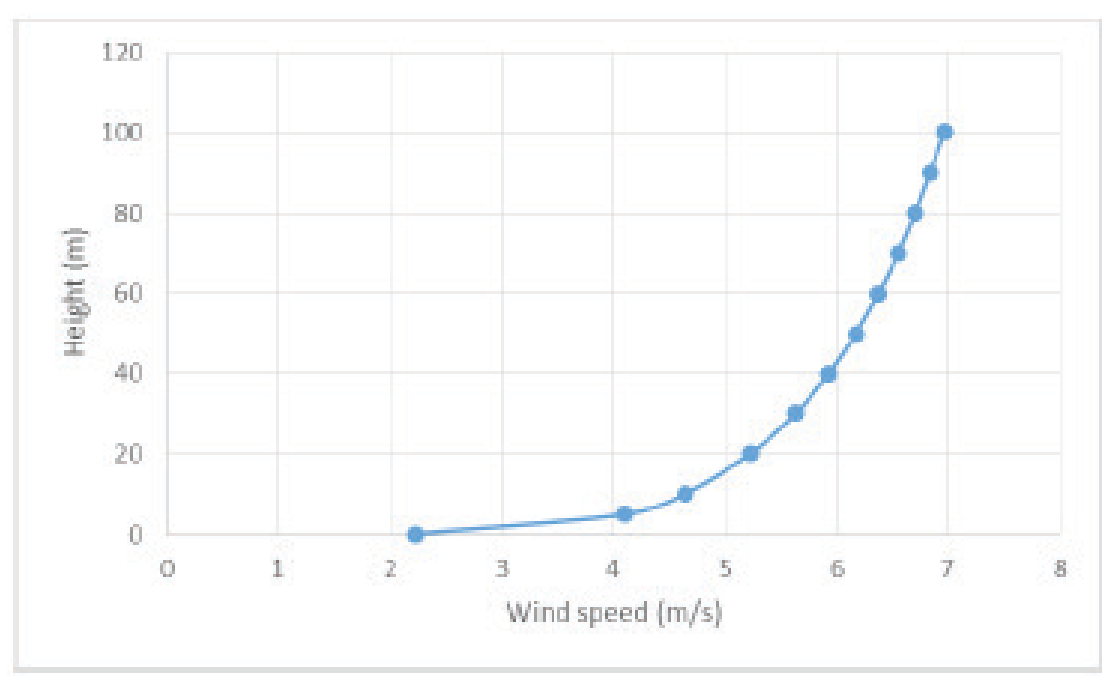

Figure (10) Vertical wind velocity profile

Wind shear exponent was used for extrapolating the wind speed to height of $100 \mathrm{~m}$. Figure 10 shows the variation of wind speeds with height. As seen in this figure, the value of wind speed at $100 \mathrm{~m}$ height was estimated to be $6.97 \mathrm{~m} / \mathrm{s}$.

\subsection{Turbulence Intensity}

Turbulence Intensity is calculated as the standard deviation of the wind speed divided by the wind speed. It is a measure of the gustiness of a wind resource. Lower turbulence results in lower mechanical loads 
on a wind turbine. 10-minute interval was used for plotting the turbulence intensity for each month. The turbulence intensity for April -2011 at $61 \mathrm{~m}$ is presented in Figure 11.

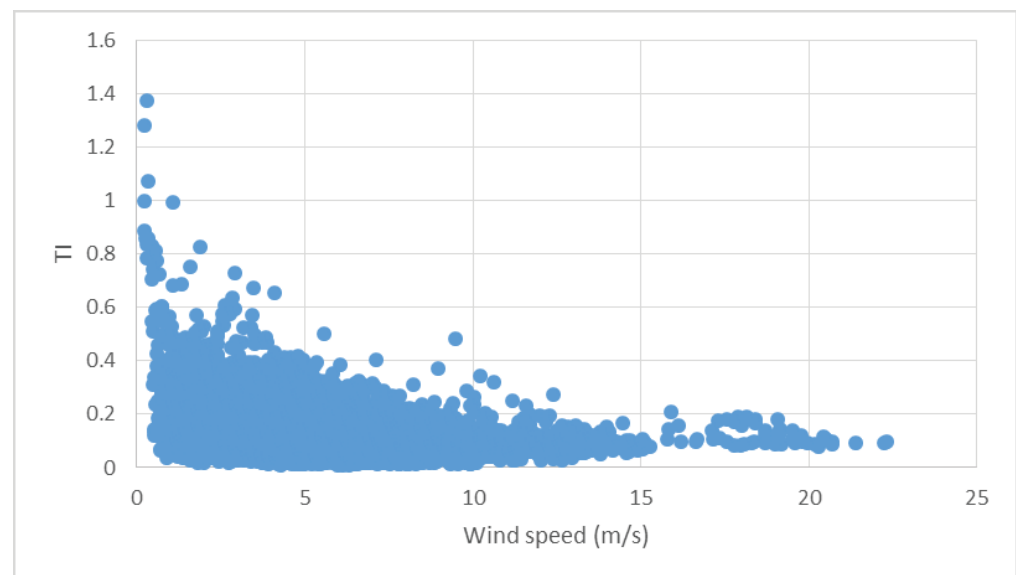

Figure (11) Turbulence Intensity vs. Wind Speed, (April-2011 at $61 \mathrm{~m}$ height)

It could be noticed that turbulence intensity is lower than 0.4 for most wind speeds above $2 \mathrm{~m} / \mathrm{s}$ and converges, approximately, to less than 0.2 at higher wind speeds.

Figure 12 shows the monthly average variation of turbulence intensity in Hun at three heights. It could be noticed that the turbulence intensity, in general, decreases with height. The highest value is recorded in March and lowest in September.

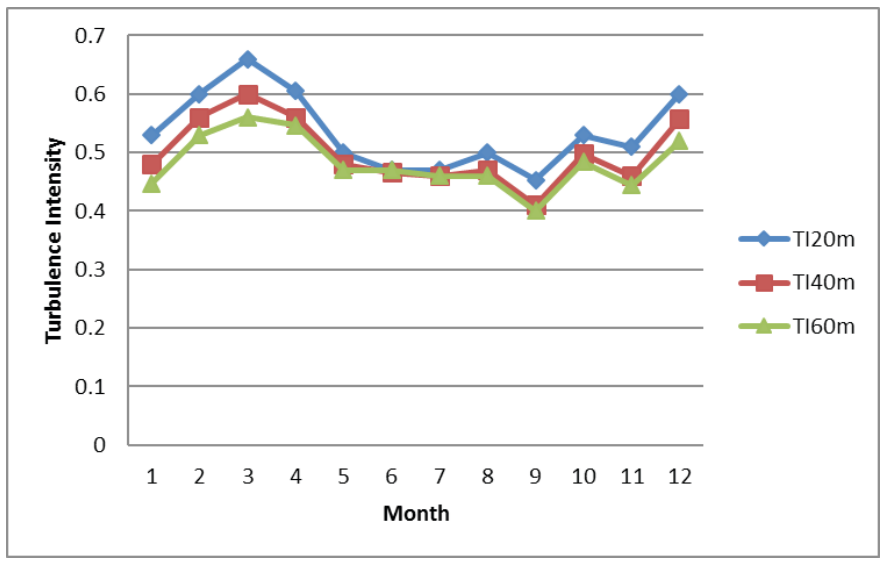

Fig (12) Monthly variation of turbulence intensity in Hun at 3- heights

\subsection{The wind speed characteristics and power densities in Hun}

The monthly and annual wind speed characteristics were evaluated for each height. Average wind speed $\left(v_{m}\right)$, standard deviation (STD), the most probable wind speed $\left(v_{F \cdot \max }\right)$, wind speed that contribute to highest energy at the site $\left(U_{E \cdot \max }\right)$, power density and energy density were evaluated for each month at the four heights. The results are presented in Tables 7 below. 
Table 7 - Monthly and annual wind speed characteristics at $60 \mathrm{~m}$

\begin{tabular}{|l|l|l|l|l|l|l|l|}
\hline \multicolumn{1}{|c|}{ Month } & $\begin{array}{c}\mathrm{v}_{\mathrm{m}} \\
(\mathrm{m} / \mathrm{s})\end{array}$ & \multicolumn{1}{|c|}{ STD } & Density & $\begin{array}{c}\mathrm{U}_{\text {F.max }} \\
(\mathrm{m} / \mathrm{s})\end{array}$ & $\begin{array}{c}\mathrm{v}_{\text {E.max }} \\
(\mathrm{m} / \mathrm{s})\end{array}$ & $\begin{array}{c}\text { ED } \\
\left(\mathrm{W} / \mathrm{m}^{2}\right)\end{array}$ & \multicolumn{1}{c|}{$\begin{array}{c}\text { ET } \\
\left(\mathrm{Wh} / \mathrm{m}^{2}\right)\end{array}$} \\
\hline Apr-11 & 6.37 & 3.48 & 1.16 & 4.92 & 10.38 & 297.23 & 214007.51 \\
\hline May-11 & 5.94 & 2.80 & 1.15 & 5.20 & 8.85 & 204.73 & 152319.10 \\
\hline Jun-11 & 5.98 & 2.79 & 1.13 & 5.27 & 8.87 & 204.05 & 146916.40 \\
\hline Jul-11 & 5.49 & 2.51 & 1.12 & 4.90 & 8.06 & 153.27 & 114032.28 \\
\hline Aug-11 & 5.23 & 2.41 & 1.13 & 4.63 & 7.70 & 134.54 & 100096.43 \\
\hline Sep-11 & 5.38 & 2.16 & 1.14 & 5.10 & 7.43 & 132.72 & 95561.63 \\
\hline Oct-11 & 4.98 & 2.41 & 1.16 & 4.28 & 7.54 & 125.39 & 93290.10 \\
\hline Nov-11 & 5.34 & 2.37 & 1.18 & 4.84 & 7.73 & 145.24 & 104575.03 \\
\hline Dec-11 & 4.66 & 2.42 & 1.21 & 3.78 & 7.35 & 114.44 & 85142.92 \\
\hline Jan-12 & 5.90 & 2.64 & 1.21 & 5.32 & 8.57 & 202.45 & 150626.01 \\
\hline Feb-12 & 6.20 & 3.28 & 1.20 & 4.95 & 9.89 & 273.69 & 190485.95 \\
\hline Mar-12 & 5.76 & 3.25 & 1.19 & 4.30 & 9.59 & 233.86 & 173994.85 \\
\hline All year & 5.60 & 2.68 & 1.17 & 4.84 & 8.43 & 176.67 & 1551868.00 \\
\hline
\end{tabular}

For example, as seen in table 4.5, the highest value of power density (ED) at $60 \mathrm{~m}$ above ground level (a.g.l.) was $297 \mathrm{~W} / \mathrm{m}^{2}$ in month of April-2011, with VE.max of $10.38 \mathrm{~m} / \mathrm{s}$ and energy density of about $214 \mathrm{kWh} / \mathrm{m} 2$.

Figure (13) shows the variation of wind power density for a whole year for four heights. Low average power density is experienced from July to December for all heights.

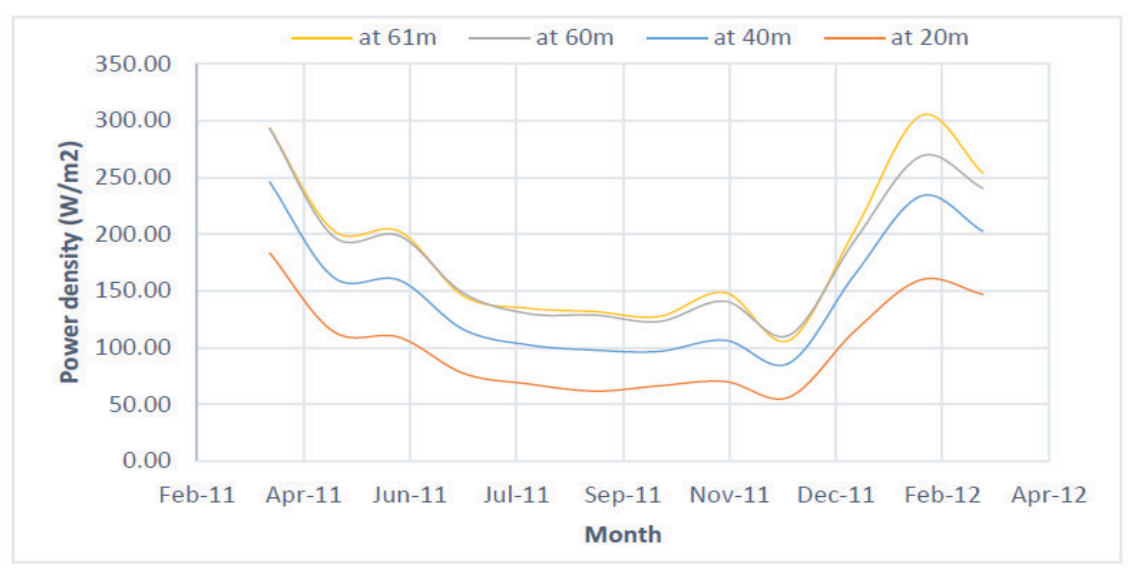

Figure (13) Variations in monthly average power densities of wind speed at different heights.

\subsection{Wind Rose}

The wind rose is a tool to determine the prominent wind direction at a site. The wind direction at Hun was analyzed using a wind rose diagram; the objective was to find the prevailing wind direction. 

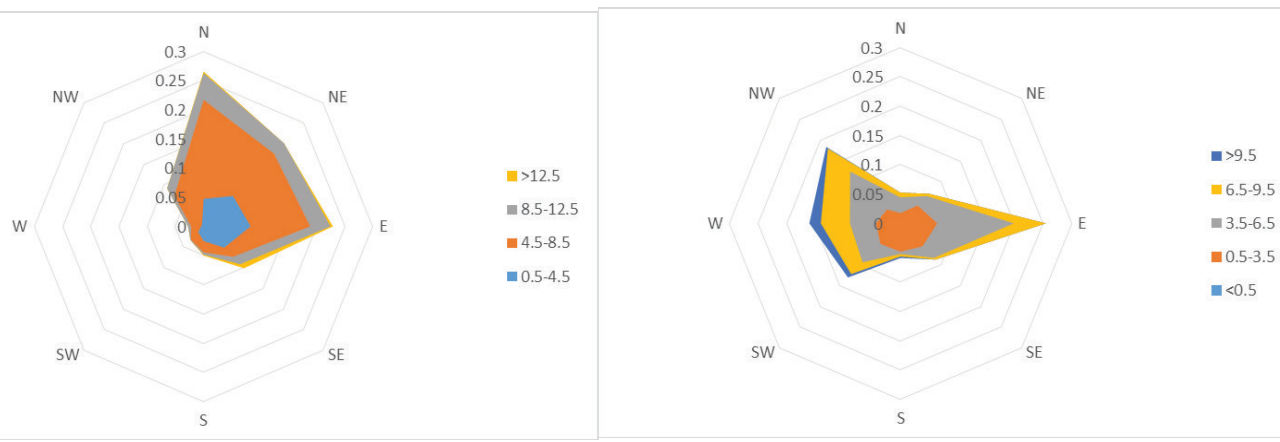

Fig (14) Wind rose of Hun wind for June 2011

Fig. (15) Wind rose of Hun for December 2011

Knowledge of the prevailing wind direction is used when decisions are made for the orientation of the wind turbines in a wind farm. The analysis was performed for each month. Results are shown for months of June 2011 (Figure 14) and December 2011 (Figure 15), as an example.

\subsection{The wind speed characteristics and power densities in Hun}

The monthly and annual wind speed characteristics are presented in Table 8 below for each height. For example, as seen in Table 8, the highest value of energy density $\left(\mathbf{E}_{\mathbf{D}}\right)$ was $306.11 \mathrm{~W} / \mathrm{m}^{2}$ at month of Feb-12, with $v_{\text {E.max }}$ of $10.33 \mathrm{~m} / \mathrm{s}$.

Table 8 - Monthly and annual wind speed characteristics at $61 \mathrm{~m}$

\begin{tabular}{|l|l|l|l|l|l|l|l|}
\hline Month & $\begin{array}{c}\mathrm{U}_{\mathrm{m}} \\
(\mathrm{m} / \mathrm{s})\end{array}$ & STD & Density & $\begin{array}{c}\mathrm{V}_{\mathrm{F} \cdot \max } \\
(\mathrm{m} / \mathrm{s})\end{array}$ & $\begin{array}{l}\mathrm{U}_{\mathrm{E} \cdot \mathrm{max}} \\
(\mathrm{m} / \mathrm{s})\end{array}$ & $\begin{array}{l}\mathrm{ED} \\
\left(\mathrm{W} / \mathrm{m}^{2}\right)\end{array}$ & $\begin{array}{l}\mathrm{ET} \\
\left(\mathrm{Wh} / \mathrm{m}^{2}\right)\end{array}$ \\
\hline Apr-11 & 6.44 & 2.64 & 1.16 & 6.05 & 8.98 & 235.61 & 169641 \\
\hline May-11 & 6.00 & 2.81 & 1.15 & 5.26 & 8.92 & 210.15 & 156354 \\
\hline Jun-11 & 6.02 & 2.80 & 1.13 & 5.3 & 8.91 & 207.68 & 149529 \\
\hline Jul-11 & 5.53 & 2.51 & 1.12 & 4.95 & 8.09 & 155.95 & 116027 \\
\hline Aug-11 & 5.26 & 2.40 & 1.13 & 4.69 & 7.72 & 136.23 & 101356 \\
\hline Sep-11 & 5.43 & 2.17 & 1.14 & 5.16 & 7.48 & 135.77 & 97753 \\
\hline Oct-11 & 5.06 & 2.43 & 1.16 & 4.37 & 7.62 & 130.09 & 96786 \\
\hline Nov-11 & 5.44 & 2.41 & 1.18 & 4.93 & 7.86 & 153.05 & 110197 \\
\hline Dec-11 & 4.78 & 2.51 & 1.21 & 3.84 & 7.59 & 124.82 & 92864 \\
\hline Jan-12 & 6.14 & 2.77 & 1.21 & 5.51 & 8.94 & 228.62 & 170093 \\
\hline Feb-12 & 6.38 & 3.45 & 1.20 & 4.99 & 10.33 & 306.11 & 213053 \\
\hline Mar-12 & 5.87 & 3.31 & 1.19 & 4.39 & 9.76 & 247.11 & 183847 \\
\hline All year & 5.69 & 2.68 & 1.17 & 4.97 & 8.49 & 182.80 & 1605485 \\
\hline
\end{tabular}




\section{10. Wind turbine selection}

The wind turbines are selected under the consideration of the following parameters resulted from the project site data analysis and turbine classification according to IEC 61400 standards:

Cut-in and cut-out wind speed

- Annual mean wind speed

- Wind speed of maximum occurrence for energy generation

- Most frequent wind speeds

- Annual gust wind speed

- Annual turbulence intensity

- The selection of hub height from the available data of turbine turbines in the market.

The reference wind speed and gust values are evaluated according to equations (19) and (20) and IEC wind turbines classifications in table (2). The results are presented in table (9).

Table 9 - Estimated extreme wind speeds for Hun

\begin{tabular}{|c|c|c|c|}
\hline Parameter & $\mathrm{H}(61 \mathrm{~m})$ & $\mathrm{H}(80 \mathrm{~m})$ & $\mathrm{H}(100 \mathrm{~m})$ \\
\hline$v_{\text {mean }}(\mathrm{m} / \mathrm{s})$ & 5.96 & 6.25 & 6.51 \\
\hline$v_{\mathrm{ref}}(\mathrm{m} / \mathrm{s})$ & 28.45 & 31.25 & 32.57 \\
\hline$v_{\mathrm{e} G 50}(\mathrm{~m} / \mathrm{s})$ & 39.83 & 43.75 & 45.6 \\
\hline$v_{\mathrm{e} \mathrm{G1}}(\mathrm{m} / \mathrm{s})$ & 29.87 & 32.8 & 34.2 \\
\hline T.I. & 0.18 & 0.18 & 0.18 \\
\hline
\end{tabular}

Therefore, the selected wind turbines for hub heights between 80 and $100 \mathrm{~m}$ a.g.l. should be of class III A. The turbines selected for this study have rated power of $2 \mathrm{MW}$ to $3 \mathrm{MW}$. The characteristics of selected turbines are available at related companies' websites [29-31]. The estimated energy output and capacity factor were calculated and the results are presented in table (10) and (11).

\subsection{Estimation of monthly energy production and capacity factor}

The total energy generated by the turbine over a period can be computed by adding up the energy corresponding to all possible wind speeds in the regime, at which the system is operational. Hence, along with the power characteristics of the turbine, the probability density corresponding to different wind speeds also comes into our energy calculations. Tables presented below show the estimated monthly energy output and capacity factor for the selected turbines.

Table 10 - Estimated Energy output, Capacity factor at hub height for selected turbines (April-2011_ September -2011)

\begin{tabular}{|l|l|l|l|l|l|l|l|}
\hline Turbine Type & & Apr. & May & June & Jul. & Aug. & Sep \\
\hline \multirow{2}{*}{ Vestas V90-2000 Gs } & $\mathrm{E}_{\text {out }}(\mathrm{kWh} / \mathrm{mo})$ & 579,831 & 527,464 & 510,884 & 448,397 & 398,571 & 396,000 \\
\cline { 2 - 8 } & $\mathrm{CF} \%$ & 40 & 35 & 35 & 30 & 26 & 27 \\
\hline \multirow{2}{*}{ Nordex N100-2500 } & $\mathrm{E}_{\text {out }}(\mathrm{kWh} / \mathrm{mo})$ & 730,740 & 669,414 & 646,507 & 567,557 & 506,939 & 504,650 \\
\cline { 2 - 8 } & $\mathrm{CF} \%$ & 41 & 36 & 36 & 31 & 27 & 28 \\
\hline \multirow{2}{*}{ Vestas V112-3000 } & Eout $(\mathrm{kWh} / \mathrm{mo})$ & 937,665 & 866,611 & 836,948 & 738,386 & 663,169 & 654,780 \\
\cline { 2 - 8 } & $\mathrm{CF} \%$ & 42 & 38 & 38 & 32 & 29 & 30 \\
\hline
\end{tabular}


Table 11 - Estimated Energy output, Capacity factor at hub height for selected turbines (October-2011_ March-2012)

\begin{tabular}{|l|l|l|l|l|l|l|l|}
\hline Turbine Type & & Oct. & Nov. & Dec. & Jan. & Feb. & Mar. \\
\hline \multirow{2}{*}{ Vestas V90-2000 Gs } & $\mathrm{E}_{\text {out }}(\mathrm{kWh} / \mathrm{mo})$ & 363,530 & 409,679 & 334,138 & 569,544 & 538,035 & 477,492 \\
\cline { 2 - 8 } & $\mathrm{CF} \%$ & 24 & 28 & 22 & 38 & 38 & 32 \\
\hline \multirow{2}{*}{ Nordex N100-2500 } & $\mathrm{E}_{\text {out }}(\mathrm{kWh} / \mathrm{mo})$ & 459,125 & 520,396 & 427,252 & 723,092 & 677,916 & 602,567 \\
\cline { 2 - 8 } & $\mathrm{CF} \%$ & 25 & 29 & 23 & 39 & 39 & 32 \\
\hline \multirow{2}{*}{ Vestas V112-3000 } & $\mathrm{E}_{\text {out }}(\mathrm{kWh} / \mathrm{mo})$ & 601,846 & 677,617 & 559,435 & 935,641 & 864,272 & 776,476 \\
\cline { 2 - 8 } & $\mathrm{CF} \%$ & 26 & 31 & 24 & 41 & 40 & 34 \\
\hline
\end{tabular}

The results presented in tables above show that Vestas V112-3000 with a hub height of $119 \mathrm{~m}$ has higher energy output and capacity factor compared to other turbines. This makes it the best choice to be installed at the site.

\subsection{Availability factor of wind turbines at the site}

The availability factor for each wind turbine at the site of Hun was calculated according to equation (21) and the results are presented in table (12). It could be noticed that Nordex N100 and Vestas V112 have higher availability factor since both have cut in wind speed of $3 \mathrm{~m} / \mathrm{s}$ and rated wind speed of $13 \mathrm{~m} / \mathrm{s}$, which is closer to the wind speed that contribute to optimum energy density at the site.

Table 12 - Availability Factor of Wind Turbines at Hun Site

\begin{tabular}{|c|c|}
\hline Wind turbine type & Availability factor $\mathbf{A}_{\mathbf{F}}$ \\
\hline Vestas V90-2000 & $71 \%$ \\
\hline Nordex N100-2500 & $83.7 \%$ \\
\hline Vestas V112-3000 & $83 \%$ \\
\hline
\end{tabular}

\section{CONCLUSIONS}

The main goal of this study was to identify and understand wind characteristics at one of the Southern locations of the country and to evaluate the potential of the site for wind generation. So, wind data was analyzed for a Southern city in Libya (Hun) using different statistical models and calculations were performed to estimate wind energy potential at the site. Energy production was investigated using different wind turbines which were selected according IEC standards criteria and performance of these wind turbines. Detailed wind data analysis was performed for the proposed site using Excel spreadsheet for one-year period from (April 2011 to March 2012). Wind data are measured at four heights of $(20 \mathrm{~m}, 40 \mathrm{~m}, 60 \mathrm{~m}$ and $61 \mathrm{~m})$ above ground level (a.g.l).

On completion of the study, the following observations can be drawn:

- Overall the monthly and annual average wind speeds in Hun are moderate, based on wind data at $61 \mathrm{~m}$ height.

- The average wind speed at the wind turbine hub height is about $6 \mathrm{~m} / \mathrm{s}$ and energy of $584,960 \mathrm{kWh} /$ month could be extracted. This average wind speed is reasonable since a minimum speed of $6.0 \mathrm{~m} / \mathrm{s}$ is needed for wind-electric generation.

- At $61 \mathrm{~m}$ height, the highest scale parameter is $7.25 \mathrm{~m} / \mathrm{s}$ in April while the lowest scale parameter is 


\section{$5.71 \mathrm{~m} / \mathrm{s}$ in October.}

- The annual shape and scale parameters range from 2.27 at $61 \mathrm{~m}$ to 2 at $20 \mathrm{~m}$, and from $6.42 \mathrm{~m} / \mathrm{s}$ at $61 \mathrm{~m}$ to $5 \mathrm{~m} / \mathrm{s}$ at $20 \mathrm{~m}$, respectively

- At this site $90 \%$ of the wind speeds are below $11 \mathrm{~m} / \mathrm{s}, 84 \%$ are below $10 \mathrm{~m} / \mathrm{s}$ and $50 \%$ are above $6 \mathrm{~m} / \mathrm{s}$.

- The highest value of the most probable or most frequent wind speed, at $61 \mathrm{~m}$ a.g.1. is $6.05 \mathrm{~m} / \mathrm{s}$ in April-2011. So the chance of its occurrence, as well as the average wind speed is acceptable.

- The highest value for the maximum energy carrier wind speed is $10.33 \mathrm{~m} / \mathrm{s}$ in February-2012. So, the chance its occurrence is moderate.

- The maximum wind speed at the site is $21 \mathrm{~m} / \mathrm{s}$ with $0.14 \%$ occurrence.

- $\quad$ The wind turbines suitable for this site should be of class III/B.

- Vestas V112-3000 gave the highest capacity factor of $42 \%$ in April and an availability of $83 \%$ while Nordex N100-2500 gave capacity factor of $41 \%$ for the same month and availability of $83.7 \%$.

- $\quad$ There is a distinct diurnal variation of the wind speed, which attains above average conditions during the early daylight hours and during the night, whilst dropping below average during the midday.

- A marked wind direction distribution is exhibited for all months at the site. Winds tend to blow from the sectors East (E) North (N), and North-west (NW) directions with comparatively few days during which the winds blow from the remaining sectors.

- The Weibull distribution is well suited for this particular area making it a handy tool for the calculation of parameters relevant to wind power generating systems.

- The site would be an acceptable site for wind energy projects, either stand alone or wind farms.

- Additional measurements may be considered for the region. However, the present work is only a preliminary study in order to estimate the wind energy potential for the location. For a comprehensive study prior to construction and installing wind energy conversion systems, more detailed studies should be performed.

\section{ACKNOWLEDGEMENT:}

The authors would like to thank Renewable Energy Authority of Libya (REAoL) for supplying wind data for this project and Center for Solar Energy Research and Studies (CSERS) for their support.

\section{CONFLICT OF INTEREST:}

The authors declare that there is no conflict of interest.

\section{FUNDS}

There is no fund received for this work. 


\section{REFERENCES}

[1]. IRENA- Renewable Capacity Statistics -2019

[2]. IRENA - Renewable energy highlights-March 2019

[3]. https://wwindea.org/blog/2019/02/25/wind-power-capacity-worldwide-reaches-600-gw-539-gw-added-in-2018/

[4]. World Wind Resource Assessment Report, WWEA Technical Paper Series (TP-01-14), December 2014

[5]. W. B. El-Osta, A. El-Taher, F. Gumati "Evaluation of Wind Energy Potential in Libya”, Applied Energy, Special Issue Proceedings, 5th Arab Int. Solar Energy Conf., Bahrain, 13-16 Nov. 1995, pp. 675-684, Elsevier Applied Science, 1995

[6]. W. B. El-Osta, M. A. Muntaser, and Y. M. Khalifa, "Wind Atlas for the Northern Coast of Libya", Proceedings of OFFSHORE WIND ENERGY IN THE MEDITERRAINEAN AND OTHER EUROPEAN SEAS: Technology and Potential Applications, OWEMES'97, 10-11 April 1997, Sardinia, Italy

[7]. A. M. Elmabrouk, "ESTIMATION OF WIND ENERGY AND WIND IN SOME AREAS (SECOND ZONE) IN LIBYA" EVRE, Monaco, March 26-29, 2009.

[8]. Dimitrios Mentis, Wind Energy Assessment in Africa A GIS-based approach, Master of Science Thesis KTH School of Industrial Engineering and Management Energy Technology EGI-2013,

[9]. Estimating the Renewable Energy Potential in Africa A GIS-based approach, IRENA, 2014

[10]. Lu, Xi, Michael B. McElroy, and Juha Kiviluoma. 2009. Global potential for wind-generated electricity. Proceedings of the National Academy of Sciences of the U. S. A.,

[11]. Wedad El-Osta, Wind Energy Potential in Libyan and its Role in Future Libyan Energy Mix, Workshop on Energy Resources Choices in Libya for Future Energy Mix, Libyan Atomic Energy Establishment, Janzour, Libya, Jan. $28,2015$.

[12]. W.B. El-Osta, and Y. Khalifa, "Prospects of Wind Energy Plants in Libya: A Case Study", Renewable Energy, 28 (2003) 363-371, Elsevier Science Ltd.

[13]. W.B El-Osta, M.A. Ekhlat, A. S. Yagub, Y. Khalifa, E Borass" Estimation of Capacity Credit for wind Power in Libya", International Journal of Energy Technology and Policy, Inderscience Pub., Vol.3, No. 4, 2005, pp 363-377.

[14]. Sathyajith Mathew, Wind Energy Fundamentals, Resource Analysis and Economics, Springer-Verlag Berlin Heidelberg 2006.

[15]. Justus, C.G.; Hargraves, W.R.; Mikhail, A.; Graber, D. Methods for estimating wind speed frequency distributions. J. Appl. Meteorol. 1978, 17, 350-353

[16]. Salahaddin A. Ahmed, Comparative study of four methods for estimating Weibull parameters for Halabja, Iraq, International Journal of Physical Sciences Vol. 8(5), pp. 186-192, 9 February, 2013

[17]. Ebru Kavak Akpinar, Sinan Akpinar, Nilay Balpetek, Statistical Analysis of Wind Speed Distribution Based on Weibull and Rayleigh Methods of ISKENDERUN-TURKEY, European Journal of Technic-EJT, Vol 8, Number 1, 2018.

[18]. Mania A. W., Kamau, J.N., Timonah, S., Analysis of Wind Energy Potential by Different Methods Based on Weibull Statistics for A Site in Juja, Kenya, Journal of Multidisciplinary Engineering Science and Technology (JMEST) ISSN: 2458-9403 Vol. 3 Issue 6, June - 2016.

[19]. Qing X, Statistical analysis of wind energy characteristics in Santiago island, Cape Verde, Renewable Energy (2017).

[20]. Emil Hernández Arroyo1, Edwin Córdoba Tuta, Gabriel García Sánchez, Comparative Analysis of the Weibull Model and Observed Wind Data in the City of Floridablanca, Colombia, TECCIENCIA, Vol. 13 No. 25, 65-70, 2018.

[21]. D.K. Kidmo $1^{*}$, R. Danwe 2, S.Y. Doka 3, and N. Djongyang, Statistical analysis of wind speed distribution based on six Weibull Methods for wind power evaluation in Garoua, Cameroon, Revue des Energies Renouvelables Vol. 18, $N^{\circ} 1$ (2015) $105-125$

[22]. H.S. Bagiorgas, G. Mihalakakou, S. Rehman, and L.M. Al-Hadhrami, 'Wind Power Potential Assessment for Seven Buoys Data Collection Stations in Aegean Sea Using Weibull Distribution Function', Journal of Renewable and Sustainable Energy, Vol. 4, Nº1, pp. 013119-1 - 013119-16, 2012.

[23]. IEC 61400-1, 3rd-ed, Wind turbines - Part 1: Design Requirements, 2005.

[24]. H. Jiang, J. Wang, J. Wu, W. Geng, Comparison of numerical methods and metaheuristic, optimization algorithms for 
estimating parameters for wind energy potential assessment in low wind regions. Renewable and Sustainable Energy Review 69, Dec. 2016.

[25]. Jianzhou Wang, Xiaojia Huang*, Qiwei Li, Xuejiao Ma, Comparison of seven methods for determining the optimal statistical distribution parameters: A case study of wind energy assessment in the large-scale wind farms of China, Energy 164 (2018).

[26]. G.M Masters,. (2004). Renewable and Efficient Electric Power Systems (pp-320), John Wiley and Sons, ISBN 0471280607 , USA.

[27]. Alan G. Davenport, C. Sue B. Grimmond, Tim R. Oke, and Jon Wieringa (200). Estimating the Roughness of Cities and Sheltered Country, American Meteorological Society.

[28]. Jon Wieringa, Ernest Rudel, Station Exposure Metadata Needed for Judging and Improving Quality of Observations of Wind, Temperature and Other Parameters.

[29]. https://en.wind-turbine-models.com/turbines/16-vestas- $v 90$

[30]. http://www.nordex-online.com/en/produkte-service/wind-turbines/n100-25-mw/product-data-sheet-n100-25mw.html

[31]. https://en.wind-turbine-models.com/turbines/693-vestas-v112-3.3 